Editorial

\title{
Special Issue on Standalone Renewable Energy System: Modeling and Controlling
}

\author{
Rodolfo Dufo-López *(1) and José L. Bernal-Agustín (i) \\ Department of Electrical Engineering, Universidad de Zaragoza, C/María de Luna, 3, 50018 Zaragoza, Spain; \\ jlbernal@unizar.es \\ * Correspondence: rdufo@unizar.es
}

Received: 12 March 2020; Accepted: 13 March 2020; Published: 19 March 2020

check for updates

\section{Introduction}

Standalone (off-grid) renewable energy systems supply electricity in places where there is no access to a standard electrical grid. These systems may include photovoltaic generators, wind turbines, hydro turbines or any other renewable electrical generator. Usually this kind of system includes electricity storage (commonly, lead-acid batteries, but also other types of storage can be used, such as lithium batteries, other battery technologies, supercapacitors and hydrogen). In some cases, a backup generator (usually powered by fossil fuel, diesel or gasoline) is part of the hybrid system.

Low-power standalone systems are usually called off-grid systems and typically power single households by diesel generators or by solar photovoltaic (PV) systems (solar home systems) [1]. Systems of higher power are called micro- or mini-grids, which can supply several households or even a whole village. Mini- or micro-grids, powered by renewable sources, can be classified as smart grids, allowing information exchange between the consumers and the distributed generation [2].

The modelling of the components, the control of the system and the simulation of the performance of the whole system are necessary to evaluate the system technically and economically. The optimization of the sizing and/or the control is also an important task in this kind of systems.

\section{Modelling and Controlling Standalone Renewable Energy Systems}

Standalone (off-grid) renewable energy systems are used all around the world, and not only in developing countries, as they are the most competitive way to supply electricity in locations where the distance to the transmission and distribution electrical grid is relatively high [3], for example in remote rural communities, farms, telecom stations, etc. Even in some cases, grid-connected systems can become off-grid systems to avoid dependence on the national grid system [4] (however, disconnecting from the grid usually implies higher cost of electricity).

When there is a unique source of energy (for example, solar home systems) the design and optimization of the system is relatively easy. However, the optimal design and operation of the hybrid off-grid systems is a difficult task, as there are many non-linear variables involved which imply that advanced optimization techniques must be used in some cases [5], for example heuristic techniques (genetic algorithms and others). Energy management in mini- and micro-grids with different sources of generation and energy storage is also non-trivial [2,6]. The optimal management of the planning is very important when the system includes fossil-fuel generators (diesel, gasoline) and batteries [7], in order to reduce fuel consumption and enhance battery lifetime.

Usually the main source of energy in the optimal hybrid off-grid system is a photovoltaic generator [8], and also includes in many cases a diesel or gasoline backup generator and battery storage. In windy places, the optimal hybrid off-grid system may also include wind turbines [9]. 
Especially in cold places, thermoelectric generators that convert thermal energy (for example, waste heat from a stove) into electricity (Seebeck effect) can be part of the optimal hybrid system [10]. However, the use of thermoelectric generators in these kind of applications is still residual.

Nowadays, most off-grid systems installed in the world include storage using lead acid batteries. However, with the recent reduction of the price of lithium batteries, these kind of batteries may be economically feasible in some cases [8,11].

\section{Future Standalone Renewable Energy Systems}

Although the Special Issue has been closed, more in-depth research of the modelling and controlling of off-grid systems is expected. The use of lithium batteries is expected to be normalized in several years and new battery technologies will emerge. Perhaps thermoelectric generators or other energy sources can be used in off-grid systems in the future.

Acknowledgments: We would like to thank the contributions of the authors' hardworking and professional reviewers. We also thank the editorial team of Applied Sciences, and give special thanks to Stella Zhang, Assistant Editor from MDPI Branch Office, Beijing.

Conflicts of Interest: The authors declare no conflict of interest.

\section{References}

1. International Energy Agency. Energy Access Outlook. 2017. Available online: https://webstore.iea.org/download/ summary/274?fileName=English-Energy-Access-Outlook-2017-ES.pdf (accessed on 10 February 2020).

2. Vera, Y.E.G.; Dufo-López, R.; Bernal-Agustín, J.L. Energy Management in Microgrids with Renewable Energy Sources: A Literature Review. Appl. Sci. 2019, 9, 3854. [CrossRef]

3. Mini Grid Policy Toolkit. European Union Energy Initiative Partnership. Dialogue Facility (EUEI PDF): Eschborn, Germany. Available online: http://minigridpolicytoolkit.euei-pdf.org/policy-toolkit.html (accessed on 10 February 2020).

4. Park, E.; Kwon, S.J.; Del Pobil, A.P. Can Large Educational Institutes Become Free from Grid Systems? Determination of Hybrid Renewable Energy Systems in Thailand. Appl. Sci. 2019, 9, 2319. [CrossRef]

5. Fathima, H.; Palanisamy, K. Optimization in microgrids with hybrid energy systems-A review. Renew. Sustain. Energy Rev. 2015, 45, 431-446. [CrossRef]

6. Khan, A.A.; Naeem, M.; Iqbal, M.; Qaisar, S.; Anpalagan, A. A compendium of optimization objectives, constraints, tools and algorithms for energy management in microgrids. Renew. Sustain. Energy Rev. 2016, 58, 1664-1683. [CrossRef]

7. Lujano-Rojas, J.M.; Yusta, J.M.; Artal-Sevil, J.S.; Domínguez-Navarro, J.A. Day-Ahead Optimal Battery Operation in Islanded Hybrid Energy Systems and Its Impact on Greenhouse Gas Emissions. Appl. Sci. 2019, 9, 5221. [CrossRef]

8. García-Vera, Y.E.; Dufo-López, R.; Bernal-Agustín, J.L. Optimization of Isolated Hybrid Microgrids with Renewable Energy Based on Different Battery Models and Technologies. Energies 2020, 13, 581. [CrossRef]

9. Dou, Y.; Zuo, G.; Chang, X.; Chen, Y. A Study of a Standalone Renewable Energy System of the Chinese Zhongshan Station in Antarctica. Appl. Sci. 2019, 9, 1968. [CrossRef]

10. Dufo-López, R.; Champier, D.; Gibout, S.; Lujano-Rojas, J.M.; Domínguez-Navarro, J.A. Optimisation of off-grid hybrid renewable systems with thermoelectric generator. Energy Convers. Manag. 2019, 196, 1051-1067. [CrossRef]

11. Jung, W.; Jeong, J.; Kim, J.; Chang, D. Optimization of hybrid off-grid system consisting of renewables and Li-ion batteries. J. Power Sources 2020, 451, 227754. [CrossRef]

(C) 2020 by the authors. Licensee MDPI, Basel, Switzerland. This article is an open access article distributed under the terms and conditions of the Creative Commons Attribution (CC BY) license (http://creativecommons.org/licenses/by/4.0/). 